\title{
Bisphosphonate-Based Molecules as Potential New Antiparasitic Drugs
}

\author{
Joice Castelo Branco Santos 1,2,+(D), Jonathas Alves de Melo ${ }^{1,3,+}$, Sweta Maheshwari ${ }^{4,+}$, \\ Wendy Marina Toscano Queiroz de Medeiros ${ }^{1,2}$, Johny Wysllas de Freitas Oliveira 1,3 (D, \\ Cláudia Jassica Moreno 1,2,3 (D), L. Mario Amzel 4 , Sandra B. Gabelli 4,5,*(D) \\ and Marcelo Sousa Silva $1,2,3,6, *$ (D)
}

1 Immunoparasitology Laboratory, Department of Clinical and Toxicological Analysis, Health Sciences Center, Federal University of Rio Grande do Norte, 59012-570 Natal, Brazil; joic.cast@hotmail.com (J.C.B.S.); biomedjonathas@outlook.com (J.A.d.M.); wendymmedeiros@gmail.com (W.M.T.Q.d.M.); johny3355@hotmail.com (J.W.d.F.O.); claudia.mrn1@gmail.com (C.J.M.)

2 Postgraduate Program in Pharmaceutical Sciences, Health Sciences Center, Federal University of Rio Grande do Norte, 59012-570 Natal, Brazil

3 Postgraduate Program in Biochemistry, Biosciences Center, Federal University of Rio Grande do Norte, 59012-570 Natal, Brazil

4 Department of Biophysics and Biophysical Chemistry, Johns Hopkins University School of Medicine, Baltimore, MD 21205, USA; sweta@jhmi.edu (S.M.); mamzel@jhmi.edu (L.M.A.)

5 Department of Medicine and Oncology, Johns Hopkins University School of Medicine, Baltimore, MD 21205, USA

6 Global Health and Tropical Medicine, Institute of Hygiene and Tropical Medicine, New University of Lisbon, 1800-166 Lisbon, Portugal

* Correspondence: gabelli@jhmi.edu (S.B.G.); mssilva@ihmt.unl.pt (M.S.S.); Tel.: +1-443-7426227(S.B.G.); Tel.: +55-84-99193-1313 (M.S.S.)

+ These authors contributed equally to this work.

Received: 4 April 2020; Accepted: 27 May 2020; Published: 3 June 2020

check for updates

\begin{abstract}
Neglected tropical diseases such as Chagas disease and leishmaniasis affect millions of people around the world. Both diseases affect various parts of the globe and drugs traditionally used in therapy against these diseases have limitations, especially with regard to low efficacy and high toxicity. In this context, the class of bisphosphonate-based compounds has made significant advances regarding the chemical synthesis process as well as the pharmacological properties attributed to these compounds. Among this spectrum of pharmacological activity, bisphosphonate compounds with antiparasitic activity stand out, especially in the treatment of Chagas disease and leishmaniasis caused by Trypanosoma cruzi and Leishmania spp., respectively. Some bisphosphonate compounds can inhibit the mevalonate pathway, an essential metabolic pathway, by interfering with the synthesis of ergosterol, a sterol responsible for the growth and viability of these parasites. Therefore, this review aims to present the information about the importance of these compounds as antiparasitic agents and as potential new drugs to treat Chagas disease and leishmaniasis.
\end{abstract}

Keywords: bisphosphonate; farnesyl pyrosphosphate synthase; leishmaniasis; chagas disease; neglected tropical diseases

\section{Introduction}

Neglected tropical diseases (NTDs) are responsible for serious public health problems in much of the world, particularly in developing countries located in Latin America, Africa, and Asia, and can also affect non-endemic developed regions, such as North America and Europe, owing to population 
migration and climate change. According to the World Health Organization (WHO), more than one billion people are affected by one or more NTDs in 149 countries [1]. Among such diseases are Chagas disease and leishmaniasis, which are caused by protozoa of the order Kinetoplastida and family Trypanosomatidae [2]. Currently, the therapeutic regimens used to control the foremost NTDs have several limitations, especially concerning pharmacological efficacy, toxicity, high costs, and complicated clinical administration. Furthermore, as these are diseases mostly related to poverty in developing countries, investment in measures to control these diseases are still insufficient [2,3]. Drugs currently used to treat Chagas disease and leishmaniasis caused by Trypanosoma cruzi and Leishmania spp., respectively, have among their disadvantages the long-term parenteral administration, development of resistance, and the requirement of complex therapeutic schemes [4,5]. Additionally, the high cost and low pharmacological efficacy justify the search for new antiparasitic drugs [6].

In recent years, several strategies have been reported aiming at the development of new drugs with antiparasitic activity, mainly in the context of infections caused by trypanosomatids, such as Leishmania spp [7-10] and T. cruzi [11-13]. In this scenario, compounds based on bisphosphonates have been gaining prominence owing to their reported antiparasitic activity [7-13]. Moreover, some of these compounds are already approved for use in humans for the treatment of some bone diseases $[14,15]$. Bisphosphonates are known to act on the classical mevalonate (MVA) pathway, which is responsible for the synthesis of essential isoprenoids in eukaryotes, archaea, and some bacterial species [16,17]. Specifically, they inhibit the farnesyl pyrophosphate synthase (FPPS), the branch point and [18] rate-limiting enzyme of the MVA pathway [19-21].

FPPS has been shown to be essential for the survival of trypanosomatid parasites_Leishmania major promastigotes as well as amastigotes and T. brucei $[8,22]$. Furthermore, FPPS can be potently inhibited by bisphosphonates in human pathogens-Toxoplasma gondii, Plasmodium falciparum, T. cruzi, T. brucei, L. major, and L. donovani [23-33]. Taken together, these findings validate FPPS as a target for drug development using bisphosphonates in the treatment of leishmaniasis as well as trypanosomiasis. Thus, the objective of this work is to present the pharmacological applications of bisphosphonates as potential antiparasitic drugs with an emphasis on the therapeutic control of Chagas disease and leishmaniasis.

\section{History of the Use of Bisphosphonates}

The synthesis of organic compounds containing phosphorous was first reported in 1820 by Jean Louis Lassaigne. At that time, alkylphosphonates were synthesized by the condensation of alcohols and phosphoric acids [34]. Later, several compounds were produced using phosphorus as the central atom, called organophosphors, such as triphosphate nucleosides and perfluoroalkylated phosphines [35]. One of the organophosphorus classes is bisphosphonates, which were initially synthesized in 1865 in Germany and have been studied extensively since the 1960s [36].

The knowledge about its use came to light owing to studies on inorganic pyrophosphate, a precursor to bisphosphonates, wherein it was observed that plasma and urine contained compounds that inhibited the precipitation of calcium phosphate and that part of this inhibitory activity was the result of inorganic pyrophosphate [15,37]. This discovery became interesting for pharmacological applications in the treatment of clinical disorders caused by the bone resorption mechanism, such as Paget's disease, osteoporosis, hypercalcemia, and fibrous dysplasia. However, pyrophosphate is metabolically unstable because it is rapidly hydrolyzed in the gastrointestinal tract. Thus, more stable compounds were sought, such as bisphosphonates [34,35].

Bisphosphonates were initially used by the chemical industry, mainly as corrosion inhibitors or as complexing agents in the textile, fertilizer, and oil industries, in addition to preventing flaking thanks to their ability to inhibit calcium carbonate precipitation [38]. Only in the last three decades have bisphosphonates been developed as drugs for use in various diseases of bone, dental, and calcium metabolism [39]. In this context, etidronate was the first bisphosphonate to be used pharmacologically in patients with ossifying myositis, a heterotopic ossification characterized by the occurrence of bone formation in soft tissues, usually muscle tissue [38,39]. 


\section{Chemical and Biological Characteristics of Bisphosphonate-Based Compounds}

Chemically, bisphosphonates are classified as a class of metabolically stable pyrophosphate analogue compounds in which the oxygen atom between the two phosphorus atoms in the pyrophosphate is replaced by a carbon atom (P-C-P bond), making these compounds resistant to chemical and enzymatic hydrolysis $[8,40]$. These compounds have the general structural formula presented in Figure 1. Additionally, bisphosphonates have two substituents in their structure, R1 and R2, linked to the geminal carbon, which allows the versatility of synthesis of this class of compounds with different pharmacological applications [41].

It is observed that, when R1 is a hydroxyl, this group, together with the phosphate groups, facilitates the association with calcium, which ensures strong interaction with bone structures. On the other hand, the R2 group is responsible for determining the bone anti-resorptive power and, depending on the class, their mechanism of action varies. Additionally, groups R1 and R2 can be extensively modified by the chemical synthesis process, enabling new derivatives for this class of molecules, consequently potentiating a diversity of biological activity [40-43].

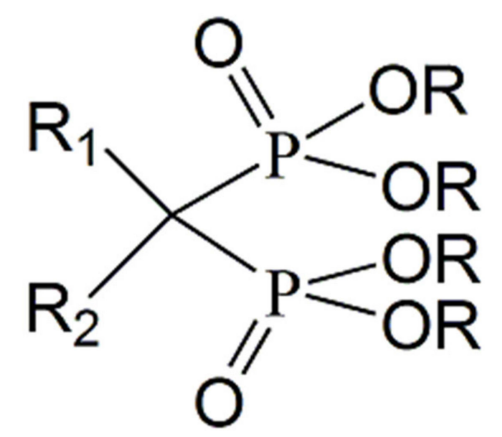

Figure 1. Basic chemical structure of bisphosphonates. The phosphate-carbon-phosphate (P-C-P) bond is the base skeleton of the structure with two covalent side chains (R1 and R2) attached to the germinal carbon. The group R1 allows higher affinity to hydroxyapatite and the group R2 increases the potency of the anti-resorptive capacity and mimic structures that give it different mechanisms of action, whether as adenosine triphosphate (ATP) analogues or isoprenoid pyrophosphate [41].

Bisphosphonate-based compounds have essential and relevant pharmacological applications. Similar to pyrophosphate, bisphosphonates exhibit a high affinity for bone hydroxyapatite and effectively prevent calcification [44]. The Food and Drug Administration (FDA) currently approves some of these compounds for the treatment of bone resorption, Paget's disease, osteoporosis, multiple myeloma, hypercalcemia associated with bone metastasis, and fibrous dysplasia $[14,15,45]$. On the other hand, in addition to their capacity as inhibitors of bone resorption, bisphosphonates are antimicrobial agents [46], anticancer agents [47], selective inhibitors of acid sphingomyelinase, and stimulators of $\gamma \delta$-T lymphocytes [48].

The antiparasitic activity of some bisphosphonates has been shown to be owing to their selective inhibitory capacity in the biosynthesis of isoprenoids [15], including in the context of infections caused by protozoa of medical importance, such as Toxoplasma gondii [12,25], Plasmodium falciparum, Trypanosoma cruzi [11-13], Trypanosoma brucei [49,50], and Leishmania spp. [7-9,25], the etiologic agents of toxoplasmosis, malaria, Chagas disease, African sleeping sickness, and leishmaniasis, respectively.

As bisphosphonates are a diversified class of chemical compounds, several methods of chemical synthesis have already been described, methods ranging from thermal dehydration at a high temperature to Michael's reaction [51,52]. The most used method to obtain bisphosphonates is the synthesis from carboxylic acids and their derivatives [53,54]. This method consists of a reaction between a carboxylic acid and a mixture of phosphorus trichloride or phosphorous acid, followed by hydrolysis under acidic conditions to produce hydroxy-bisphosphonates or 
their sodium salts (Figure 2). Other methods of synthesis have been described, such as phosphonalkylation [55,56], from bisphosphonate fractions [57,58], by a cross-coupling reaction [59], from aminomethylene-phosphonic acids [60,61], by radical reaction [62,63], from halo substrates [64], and from functional nitrogen substrates [65].

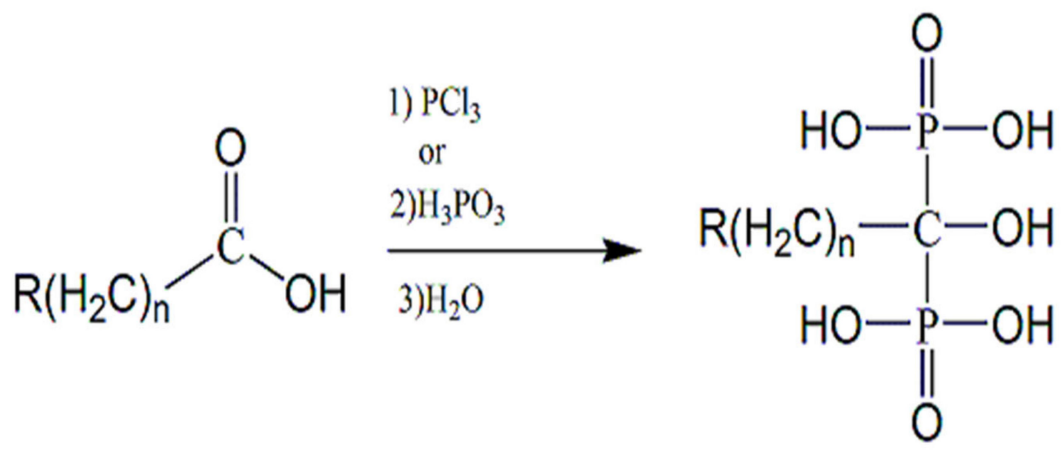

Figure 2. Classical route for the synthesis of hydroxy-bisphosphonates. The method requires the addition of (1) phosphorus trichloride or (2) phosphorous acid to that of carboxylic acid, followed by (3) hydrolysis to generate the bisphosphonate.

Bisphosphonates are classified according to the presence or absence of nitrogen in their R2 side chain, as shown in Figure 3 [66]. Depending on the side chain inserted into the central carbon atom, the pharmacological characteristics of these compounds vary such as absorption, distribution, retention, elimination, renal excretion, and inhibition of cellular activity and mechanisms of action. Non-nitrogenated bisphosphonates, analogous to pyrophosphates, lead the cell to apoptosis owing to its toxicity when metabolized as adenosine triphosphate (ATP). However, nitrogenated bisphosphonates, similar to isoprenic pyrophosphate, are not metabolized and act by inhibiting the enzyme farnesyl pyrophosphate synthase (FPPS), thereby reducing prenylation of guanosine triphosphate (GTP)-binding proteins (such as Rho, Rab, Rac, and Cdc42) that are essential for osteoclast activity and survival [52,67,68].

Applications of bisphosphonates range from insecticides and herbicides [35,69] to drugs for the treatment of diseases such as osteoporosis, Paget's disease, and parasitic diseases [27,70-72]. This comprehensive action is the result of the structural diversity of these compounds. The molecular variations of bisphosphonates over the decades allowed classifying them according to the synthesized structure. The first-generation bisphosphonates derivatives do not have nitrogen in their structures [73-77]. The second-generation compounds are of nitrogen-containing compounds with an alkyl chain of up to five carbon atoms [78,79]. Finally, third-generation compounds are compounds that have a branched $\mathrm{N}$ chain, or ring formation [80-82].

Compounds based on bisphosphonates belonging to the second and third generation are the main compounds with inhibitory activity on farnesyl pyrophosphate synthase (FPPS), an essential enzyme in the mevalonate pathway, responsible for the production of isoprenoids, such as cholesterol and ergosterol [83]. The mevalonate pathway plays a crucial biological role in eukaryotes. This metabolic pathway is responsible for the production of cholesterol/ergosterol, maintenance of cell membrane and organelles, biosynthesis of steroids, and other processes involving cellular signaling. Disorders in this metabolic pathway can cause toxicity, alteration of cellular structure and function, as well as loss of homeostasis [84]. 

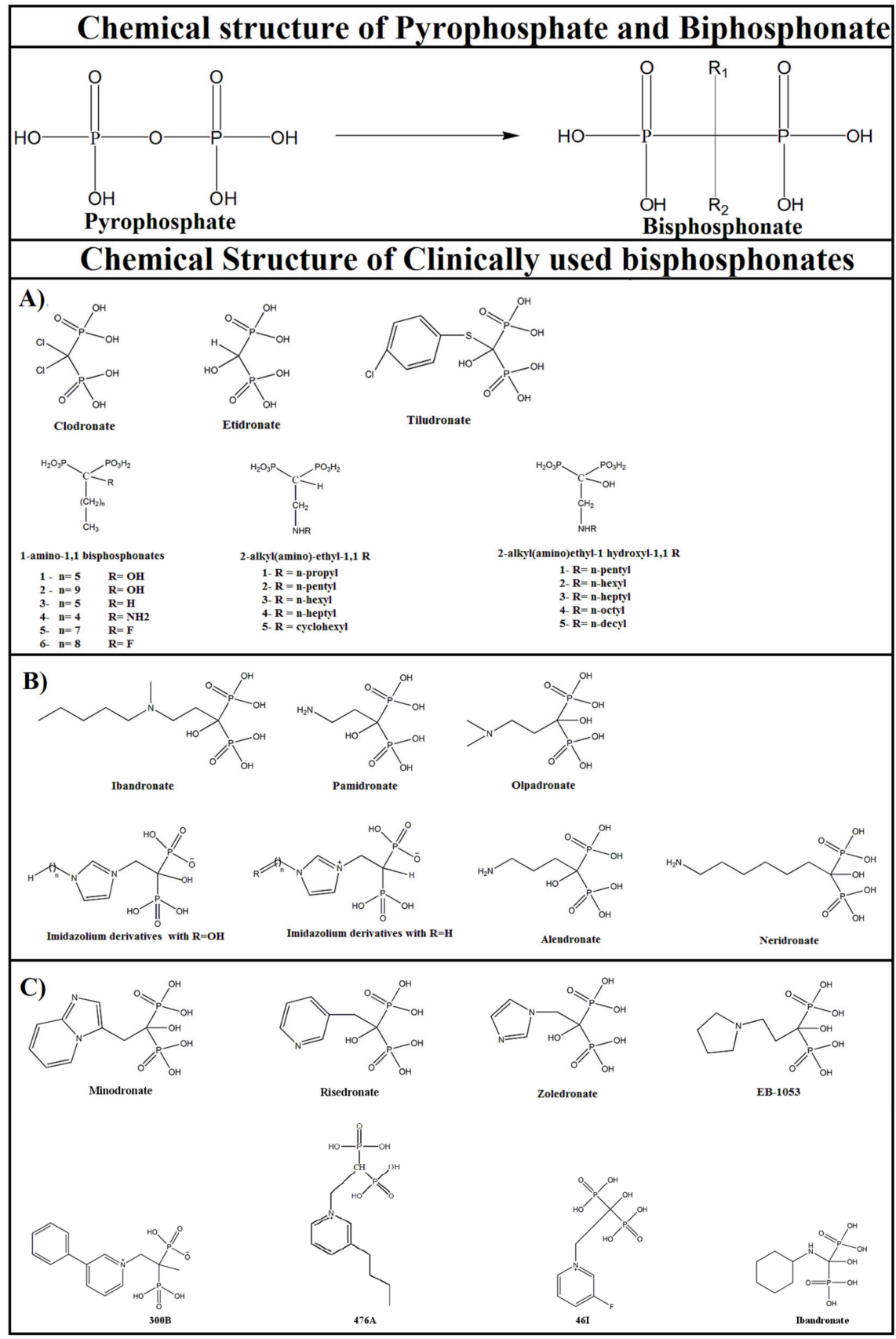

Figure 3. Chemical structures of pyrophosphonate, bisphosphonate, and bisphosphonates used clinically [41, 85]. First generation (A); second generation (B); and third generation of bisphosphonates compounds (C).

Experimental evidence has shown that second- and third-generation nitrogenous bisphosphonates are generally more potent than conventional bisphosphonates in inhibiting bone resorption $[14,82]$. However, the main disadvantage of administering these compounds is related to toxicity, as it can induce the development of severe osteonecrosis and gastric inflammation in humans $[70,86]$. Even with toxicity, these nitrogen-containing compounds are still recommended in clinical practice, particularly in terminal cancer patients with hypercalcemia or bone metastasis, as these compounds act as calcium chelators. Furthermore, the use of these compounds is also justified in the process of bone resorption, preventing fractures and osteolytic progression, and consequently reducing bone pain [70].

Conventional bisphosphonates participate in metabolic reactions, mainly in ATP biosynthesis. On the other hand, nitrogenous bisphosphonates can act on the mevalonate pathway through the inhibition of 
the FPPS enzyme [14]. The FPPS enzyme catalyzes two-step reactions. In the first step, isopentenyl pyrophosphate (IPP) and its dimethylalyl pyrophosphate isomer (DMAPP) undergo condensation to form geranyl pyrophosphate (GPP) and farnesyl pyrophosphate (FPP), important isoprenoid intermediates [8,14]. Isopropenoids are essential molecules of the cellular machinery of eukaryotic and prokaryotic organisms, as an example, the trypanosomatids parasites and bacteria, respectively. These molecules are involved in several biological processes, such as cell differentiation and growth and antioxidant activity [40,87]. These intermediate precursors are essential for the formation of most isoprenoids, including ergosterol, a sterol whose inhibition results in changes in the integrity of the lipid bilayer of cells, leading to their death $[8,88]$. These reactions are represented schematically in Figure 4.<smiles>CC(C)=CCOP(=O)([O-])OP(=O)([O-])[O-]</smiles>

Dimethylalyl pyrophosphate (DMAPP)

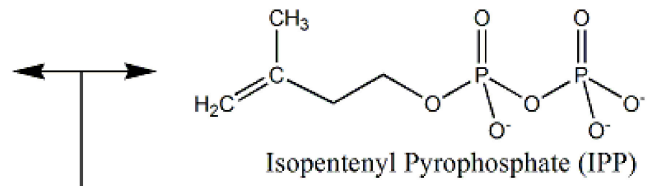

Farnesyl Pyrophosphate Synthase (FPPS)

$Y$<smiles>CC(C)=CCC/C(C)=C/COP(=O)(O)OP(=O)(O)O</smiles>

Geranyl Pyrophosphate (GPP)

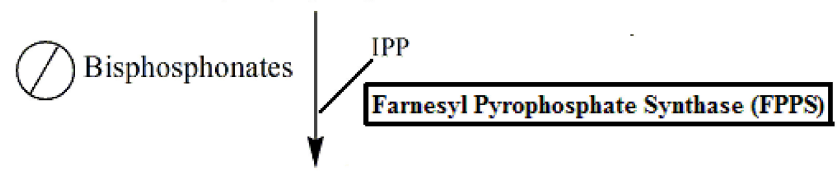<smiles>CC(C)=CCC/C(C)=C/CC/C(C)=C/COc1ccccc1</smiles>

Farnesyl Pyrophosphate (FPP)

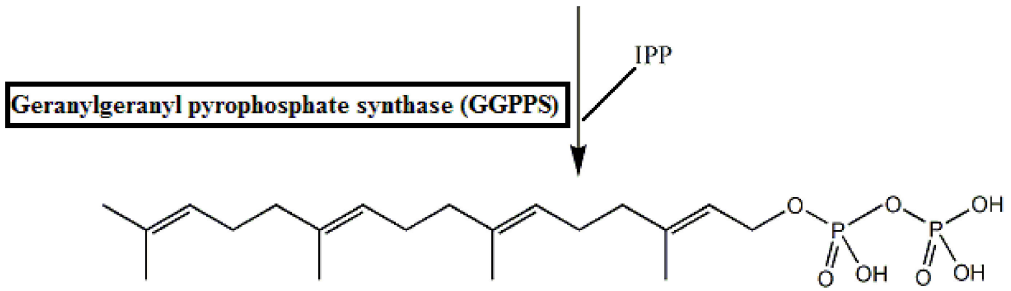

Geranylgeranyl pyrophosphate (GGPP)

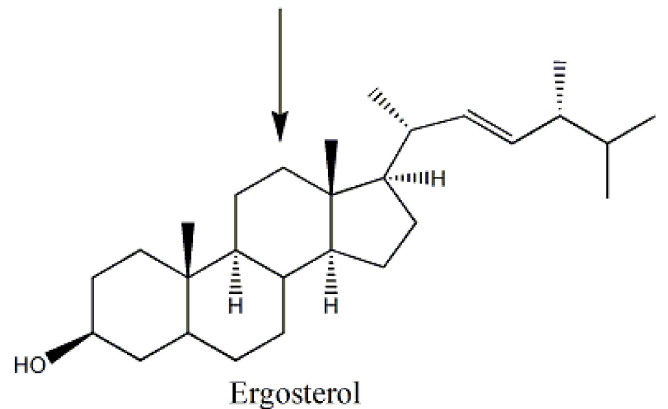

Figure 4. Schematic representation of the mevalonate pathway and the action of nitrogen-containing bisphosphonates. These compounds inhibit the enzyme farnesyl pyrophosphate synthase (FPPS), preventing the synthesis of farnesyl pyrophosphate (FPP) and geranylgeranyl pyrophosphate (GGPP) necessary for protein prenylation and subsequent ergosterol formation in eukaryotic cells. 


\section{Bisphosphonate Compounds as Potential New Anti-Trypanosoma cruzi Drugs}

American trypanosomiasis, also known as Chagas disease, was first described in 1909 by physician Carlos Chagas, after identifying and characterizing the etiologic agent, the hemoflagellate protozoan Trypanosoma cruzi [89]. Chagas disease is considered by the WHO to be an NTD that spreads beyond endemic countries through population migration. Among the countries affected are the United States, Canada, European countries, and some Pacific countries [90]. The main mechanisms of transmission of Chagas disease are vector, blood transfusion, organ transplantation, and congenital transmission, all of which contribute to the spread of the disease [90-93]. It is estimated that around 7 million people worldwide are infected with Chagas disease, with 6 million cases present in 21 countries in Latin America [94]. Furthermore, it is estimated that approximately 70 million people are at risk of contracting this disease, which is responsible for around 14,000 deaths per year [95]. Worldwide, $1 \%$ to $10 \%$ of children infected with T. cruzi are born with congenital Chagas disease [96] and the Pan American Health Organization (PAHO) estimates that 25\% of new infections are congenitally transmitted $[97,98]$. Even in the USA, a non endemic country, the maternal-to infant transmission rate is estimated to be $1-5 \%$ [99]. T. cruzi infected infants may present with low birth weight, prematurity, hepatosplenomegaly, meningoencephalitis, and anemia [100-102].

Chagas disease can be considered as one of the most important NTDs in the world together with malaria and schistosomiasis. This disease presents a short period of acute phase-of eight to twelve weeks-and a prolonged chronic phase — of twenty to thirty years. In the chronic phase of the disease, the parasites may compromise the normal function of the cardiac apparatus, progressing to dilated cardiomyopathy that display cardiac arrhythmias, conduction abnormalities, and heart failure [103]. Other manifestations of this stage include digestive alterations, causing megacolon and megaesophagus, and consequently causing difficulties of swallowing, asphyxia, aspiration pneumonia, chronic constipation, and abdominal pain [94,96].

For more than 50 years, treatment for Chagas disease has been based on the use of two drugs, Benznidazole and Nifurtimox. Benznidazole is a nitroimidazole derivative, and its mechanism of action is supposed to be through reductive stress that involves covalent bonds to macromolecules vital to the parasite. Nifurtimox, in turn, is a nitrofuran that produces oxidative metabolites, such as oxygen peroxide, as the parasite does not have efficient mechanisms for detoxifying the produced substrates. In Brazil, Benznidazole is used as the drug of choice for the treatment of Chagas disease, despite its low effectiveness during the chronic phase of infection [92,104].

These drugs have pharmacological activity essentially in the acute phase of infection caused by T. cruzi, resulting in pharmacological efficacy of around $80 \%$ of treated patients. However, in the chronic phase of the infection, the effectiveness can vary from $7 \%$ to $10 \%$ for Nifurtimox and from $2 \%$ to $40 \%$ for Benznidazole [92]. In addition to the low pharmacological efficacy of these drugs in the chronic phase of infection, these compounds still have high toxicity, causing adverse reactions, such as anorexia, weight loss, neurological disorders (irritability, insomnia, disorientation, mood changes, paresthesia, and peripheral neuropathy), digestive manifestations such as nausea and vomiting, and sometimes fever and rash, leading to the patient often abandoning treatment [91,105].

Currently, Nifurtimox and Benznidazole are the two drugs used in the acute phase of the disease [106-108]. No effective treatment is available for the chronic phase of the disease. As the PAHO established in their 2018 recommendations, there is an urgent need to develop new drugs able to cure the trypanosome infection as well as drugs to reverse heart damage [98]. In this context, some enzymes involved in the synthesis of sterols in T. cruzi have been shown as potential targets for the development of anti-T. cruzi drugs. One of these enzymes is farnesyl pyrophosphate synthase (FPPS), which seems to be an adequate pharmacological target for the inhibitory action of bisphosphonates [32].

In T. cruzi, the use of bisphosphonates with antiparasitic activity seems to be feasible, as the R2 grouping of these molecules has the ability to interact and inhibit farnesyl pyrophosphate synthase (FPPS), causing a reduction in levels of FPPS and geranylgeranyl pyrophosphate (GGPP) [109]. The inhibitory action of these compounds on FPPS may play an important role in the functionality 
of these molecules by reducing the production of several sterols and poly-isoprenoids, such as farnesylated proteins [110,111], Heme-A [112], Dolichol-PP [113], ubiquinones [114], and the synthesis of ergosterol [115]. These molecules are of fundamental importance for the survival of the parasite, as they trigger relevant functions in the structure of membranes.

In this context, studies performed by Martin et al. [49] were the first to demonstrate that nitrogen-containing bisphosphonates inhibit the in vitro proliferation of $T$. cruzi, with $\mathrm{IC}_{50}$ (the concentration required to reduce the parasitemia by half) in the micromolar range. In addition, these compounds showed a broad range of antiparasitic activity in other trypanosomatids (T. brucei and L. donovani) as well as apicomplexan parasites (T. gondii and P. falciparum). In particular, zoledronate appeared to be the most effective, with an $\mathrm{IC}_{50}$ of $35 \mu \mathrm{M}$ against $\mathrm{T}$. cruzi amastigote replication. These studies also suggested that the observed effects of bisphosphonates were the result of the inhibition of sterol biosynthesis, at the level of FPPS enzyme [27].

Bouzahzah and collaborators [116] evaluated the antiparasitic activity of the risedronate compound in mice infected with T. cruzi. This study indicated that, when the compound was administered subcutaneously, there was a significant reduction in animal mortality. However, the myocardial phenomenon and the dilation of the animals' right ventricle remained unchanged in the animals, when compared with the control group. According to Garzoni and collaborators [13], risedronate is capable of inducing antiparasitic activity by reducing the growth of T. cruzi epimastigotes in vitro. This antiparasitic phenomenon was characterized by the ability of this compound to deplete the parasite's endogenous sterols. Thus, risedronate treated parasites showed a variety of changes such as ultrastructural changes including mitochondrial edema, disorganization of organelles such as reservosome and kinetoplast, along with the appearance of autophagic vesicles and progressive vacuolization of the cytoplasm. Additionally, risedronate also displayed antiparasitic activity in the amastigote form of T. cruzi, an intracellular form responsible for the chronic phase of Chagas disease.

Another interesting study by Montalvetti and collaborators reported that nitrogen-containing bisphosphonates_risedronate, alendronate, and pamidronate $\left(\mathrm{IC}_{50} \sim 7 \mathrm{~nm}-1 \mu \mathrm{M}\right)$-were more potent than non-nitrogen containing bisphosphonate and etidronate $\left(\mathrm{IC}_{50} \sim 58 \mu \mathrm{M}\right)$ in inhibiting T. cruzi FPPS (TcFPPS) [22]. Similar results have also been reported for the human enzyme [117]. Pamidronate not only blocked the intracellular growth of T. cruzi amastigotes in vitro, but also substantially suppressed the proliferation of the parasite in vivo when tested in a murine model of acute Chagas disease [118]. It has been postulated that the antiparasitic activity of nitrogen-containing bisphosphonates could be owing to their preferential accumulation in the calcium and pyrophosphate-rich acidic organelles of the parasite named as acidocalcisomes [118]. A similar explanation has been suggested for the antiresorptive activity of these compounds that is based on their ability to bind avidly with calcium hydroxypatite in the bone mineral $[29,119]$.

On the other hand, bisphosphonates derived from fatty acids, in which no nitrogen atom is present in R2 side chain, were also shown to be potent inhibitors of amastigote forms of T. cruzi as well as the target enzyme TcFPPS with $\mathrm{IC}_{50}$ values at the low micromolar level [120]. To further elaborate on non-nitrogenous bisphosphonates, there are at least three categories of these bisphosphonates derived from fatty acids that have been purposely designed as anti-parasitics [22,27,121]: 1-amino-1,1; 1-hydroxyl-1,1; and 1-alkyl-1,1 bisphosphonates (Figure 3A).

The inhibitory activity of 1-amino-1,1 bisphosphonates increases with length of the carbon chain [27]. For example, the compound with $n=4$ inhibits TcFPPS with nanomolar affinity and is more potent than the 1-hydroxyl-1,1 bisphosphonate $(n=4)$ against TcFPPS [22]. However, 1-hydroxy class of bisphosphonates $(n=4$ and 5 ) are potent inhibitors of TcFPPS compared with 1-alkyl bisphosphonates $(n=4$ and 5). On the other hand, the fatty acid fluorine derivatives of bisphosphonates have relatively lower activity against T. cruzi amastigotes, but are potent inhibitors of T. gondii tachyzoites, with $\mathrm{IC}_{50}$ in the low nanomolar range [122].

The differential biological activities of different bisphosphonate pharmacophores across trypanosomatids are further displayed in the 2-alkyl(amino)-ethyl-1,1 bisphosphonate series (Figure 3A). 
The 2-alkyl(amino)-ethyl derivatives ( $n=5$ and 6) have higher biological activity than their counterparts 2-alkylaminoethyl-1-hydroxy-1,1 bisphosphonates against $T$. cruzi amastigotes $[22,50,121,123]$. Furthermore, the 2-alkyl(amino)ethyl derivatives with $n>3$ are more potent $\left(\mathrm{IC}_{50}\right.$ in the nanomolar range) than the parent pharmacophores, 1-hydroxy, 1-alkyl, and 1-amino bisphosphonates, as growth inhibitors of trypanosomatids. Surprisingly, the 2-alkylaminoethyl-1-fluoro-1,1 bisphosphonates synthesized by Galaka et al. by replacing hydrogen with fluorine atom at C-1 position rendered these compounds inactive for T. cruzi amastigotes as well as T. gondii tachyzoites [40].

However, it is important to note that most clinically approved drugs for bone-related disorders are nitrogen containing owing to their superior ability in suppressing osteoclast survival. These constitute the second and third generation of bisphosphonates with nitrogen containing R2 side chain. Thus, some novel strategies have been reported to increase the potency of these nitrogen containing bisphosphonates for repurposing as antiparasitic drugs. In one such study, bioactive ligand risedronate was coordinated with different first row transition metal ions- $\mathrm{Cu}, \mathrm{Co}, \mathrm{Mn}$, and $\mathrm{Ni}-\mathrm{in}$ an effort to generate a synergistic and additive effect of the ligand metal complex. These complexes in particular 'Mn risedronate complex' demonstrated stronger inhibition $\left(\mathrm{IC}_{50} \sim 14 \mu \mathrm{M}\right)$ with low cytotoxicity in mammalian Vero cells compared with the free risedronate ligand $\left(\mathrm{IC}_{50} \sim 55 \mu \mathrm{M}\right)$ against proliferation of T. cruzi amastigotes [124]. Similarly, bisphosphonate ibandronate was also complexed with these transition metals and evaluated for anti-proliferative effects on TcFPPS. In addition to exhibiting improved inhibition of T. cruzi amastigotes, these metal complexes also showed a poor inhibition for human FPPS $\left(\mathrm{IC}_{50} \sim 10 \mu \mathrm{M}\right)$ than free ibandronate $\left(\mathrm{IC}_{50} \sim 0.96 \mu \mathrm{M}\right)[121]$.

In another study by Yang and colleagues, bisphosphonates for treatment of trypanosomiasis were selected on the basis of the enzymatic activity inhibition as well as cell growth inhibition with low human cell toxicity as assessed in HEK293 cells. In this study, the zoledronate derivatives containing imidazolium side chain with $n=0-8$, with and without 1-hydoxyl (1-OH) in the bisphosphonate backbone, were as potent as bisphosphonates with pyridinium side chain against TbFPPS (Figure 3B) [83]. Thus, the antiparasitic activity of bisphosphonate compounds against T. cruzi parasites in vitro as well as in vivo justifies the need for further research that can contribute to the development of these compounds as potential new drugs for the treatment of Chagas disease.

\section{Bisphosphonate Compounds as Potential New Anti-Leishmania spp. Drugs}

Leishmaniasis is a group of parasitic diseases caused by trypanosomatids belonging to the genus Leishmania [125]. These trypanosomatids affect humans; several species of wild and domestic mammals; as well as invertebrates belonging to the order Diptera, family Psychodidae, genus Lutzomya in the New World, and genus Phlebotomus in the Old World [126]. The Leishmania specie is classified into two subgenera-Leishmania Viannia and Leishmania Leishmania-according to their clinical and epidemiological characteristics [127].

According to WHO [128], leishmaniasis is endemic in tropical and subtropical areas and in the Mediterranean basin, affecting 98 countries and about 12 million people. It is estimated that more than 1 billion people live in endemic regions at risk of infection. In addition, about 1.3 million new cases of the disease are registered annually, and mortality is 20,000 to 30,000 per year $[128,129]$. This disease is endemic in five continents, in 98 countries located mainly in tropical and subtropical regions, where socioeconomic status impacts disease control [95-97]. The clinical forms of leishmaniasis are visceral leishmaniasis (VL) and cutaneous leishmaniasis (CL) [130]. The factors that determine the different clinical forms are the species of the infectious agent, which vary according to the geographical area.

In the last decades, few drugs have been made available for the treatment of leishmaniasis, among which none is suitable for treatment owing to high toxicity, prohibitive prices, intravenous administration that requires hospitalization [131], and the risk of developing drug resistance [118]. In Brazil, mainly in northeastern Brazil, leishmaniasis presents a variety of clinical spectra, characterized by tegumentar leishmaniasis and visceral leishmaniasis. Owing to the exposure of U.S. troops to both 
visceral and cutaneous leishmaniasis, after the deployments in the Middle East, the United States has observed infections. In fact, the army has developed a topical to treat cutaneous leishmaniasis. As of 2007, about 1300 soldiers have been diagnosed with leishmaniasis [132-134], but the real problem is the threat of leishmaniasis infection of autochthonous cases within the USA and the expansion of the natural borders of Leishmania mexicana beyond Texas [135-137].

The drugs approved by the FDA for the treatment of leishmaniasis are as follows: (i) Pentavalent antimonials_-meglumine antimoniate and sodium stibogluconate-first-line drugs of choice, but when accumulated in organic tissues, they can cause serious adverse effects, such as vomiting, severe nausea, anorexia, headache, arthralgia, lethargy, cardiotoxicity, pancreatitis, and nephrotoxicity [138]; (ii) Amphotericin B, also of the first line of choice; however, it can cause chills and fever, associated with myocarditis and nephrotoxicity, in addition to a high cost for liposomal formulation [139]; (iii) Pentamidine, a second-line drug for patients resistant to antimony; however, it was discontinued owing to severe adverse reactions such as myocarditis, headache, hypotension, hyperglycemia, and hypoglycemia [140]; (iv) Paromomycin, an aminoglycoside antibiotic used in the topical treatment of CL and as an alternative to VL; however, it causes respiratory dysfunction and changes in lipid metabolism [117]; and (v) Miltefosine, an oral therapeutic drug for the treatment of all forms of leishmaniasis, which was approved in 2014 [141,142]. However, the use of Miltefosine is contraindicated for pregnant women and nursing mothers, because it is a teratogenesis drug.

Besides the limitations of currently used drugs, the failure of treatment owing to low plasma concentration [143] highlight the necessity to develop effective anti-leishmaniasis drugs with reduced side effects. In recent years, several approaches have been reported to identify and optimize bisphosphonates as new drugs against Leishmania spp. parasites [144]. Initial studies by Martin at al. evaluating the activities of various nitrogen containing bisphosphonates on the intracellular proliferation of L. donovani amastigotes demonstrated that risedronate was most effective with an $\mathrm{IC}_{50}$ of $2.3 \mu \mathrm{M}$ with little toxicity to host cells [27]. Further studies on nitrogen-containing bisphosphonates as potential anti-Leishmania drugs were performed by Yardley and collaborators [25]. These authors carried out preclinical tests in mice infected with L. donovani and evaluated the antiparasitic activity in vivo of three bisphosphonate-based compounds, namely, alendronate, pamidronate, and risedronate. Alendronate did not show antiparasitic activity against L. donovani. However, the compounds pamidronate and risedronate showed antiparasitic activity when administered by intravenous or intraperitoneal routes. In 2002, another study published by Rodriguez et al. demonstrated the antiparasitic activity of pamidronate in an experimental model of L. mexicana amazonensis [10]. Pamidronate, when administered intraperitoneally with a dose of $10 \mathrm{mg} / \mathrm{kg} / \mathrm{day}$, for five days, cured mice with cutaneous leishmaniasis with a healing process characterized by the extinction of lesions over time and the disappearance of amastigote forms at the lesion site, as determined by polymerase-chain reaction.

To investigate the target of bisphosphonates, Ortiz-Gómez and collaborators studied the effects of bisphosphonate risedronate on L. major parasites overexpressing FPPS. In these studies, L. major promastigotes were transfected with FPPS and the resulting tranfectants were characterized for the overexpression of FPPS. The $\mathrm{IC}_{50}$ for risedronate against these parasites overexpressing LmFPPS was found to be 70 times higher than the wild-type cells, indicating the correlation of degree of resistance with the increase in enzyme activity. Furthermore, when resistance was induced by stepwise selection with increasing concentrations of risedronate, the resulting resistant promastigotes exhibited a fourfold increase in the levels of FPPS as a result of drug pressure. These studies further suggested that FPPS is the main target of amino bisphosphonates in Leishmania [9].

Another interesting study by Gadelha and colleagues evaluated the effects of N-BPs on the cell viability and ultrastructure of L. infantum, the FPPS of which is about 97\% identical to that of L. major. The N-BP risedronate had stronger anti-proliferative activity against L. infantum promastigotes with an $\mathrm{IC}_{50}$ of $13.8 \mu \mathrm{M}$ compared with other N-BPs such as ibandronate $\left(\mathrm{IC}_{50}=85.1 \mu \mathrm{M}\right)$ and alendronate $\left(\mathrm{IC}_{50}=112.2 \mu \mathrm{M}\right)$. In addition, the three N-BPS displayed the same ultra-structural alterations in 
L. infantum promastigotes, such as accumulation of small vesicles in the Golgi region, mitochondrial swelling, altered cell division, formation of intracellular vesicles and lamellae, plasma membrane blebbing, as well as nuclear pyknosis and chromatin condensation [145].

To further understand the interaction of N-BPs with the target enzyme FPPS in L. major, the binding affinities of nitrogen-containing bisphosphonates derivatives with pyridinium (e.g., 300B, 46I, and 476A) or imidazolium side chains (e.g., zoledronate/91B) (Figure 3C) were probed by isothermal titration calorimetry. The binding affinity or $\mathrm{K}_{\mathrm{d}}$ values for LmFPPS against these inhibitors were in the range of 28-343 nM. Of particular interest was zoledronate, as it exhibited five times higher affinity $\left(\mathrm{K}_{\mathrm{d}} \sim 28 \mathrm{nM}\right)$ for Leishmania major FPPS compared to human FPPS $\left(\mathrm{K}_{\mathrm{d}} \sim 150 \mathrm{nM}\right)[7,146]$. Furthermore, zoledronate was also found to have an inhibition constant or Ki of $11 \mathrm{nM}$ for LmFPPS using inhibition studies, suggesting its high potency [123]. The differential activities and affinities of these bisphosphonates for human and Leishmania FPPS enzymes could be greatly exploited to design more effective parasite-specific inhibitors. Despite these initial studies on the use of bisphosphonates in experimental leishmaniasis therapy, further in vivo studies are needed to validate the use of these compounds as potential parasitic-specific therapies for the treatment of leishmaniasis.

\section{Overall Structure of LmFPPS and TcFPPS in Complex with Inhibitors}

FPPS enzymes are dimers with an extensive buried surface area of about $3000 \AA^{2}$ [147]. The structures of trypanosomatids and human FPPS in complex with a bisphosphonate inhibitor (risedronate/zoledronate or other N-BPs), substrate IPP, and three divalent cations (either $\mathrm{Mg}^{2+}$ or $\mathrm{Ca}^{2+}$ ) have been determined by X-ray crystallography $[7,11,147,148]$ (Figure 5A). In the structures of these complexes, the nitrogen containing BP inhibitors occupy the allylic site and IPP (when present) occupies the homoallylic site. An overall 'closing' of the active site is observed in the structures of these complexes when compared with the apo structure [148]. Three divalent cations bridge the side chains of aspartate residues from the two aspartate-rich motifs (DDXXD; residues 98-102 in the first aspartate-rich motif and residues 250-254 in the second aspartate-rich motif) to coordinate the bisphosphonate atoms of the inhibitor bound at the allylic site $[83,147,148]$. Each divalent cation is coordinated by water molecules and oxygen atoms of the bisphosphonate. On the other hand, the phosphate oxygen atoms of the IPP are recognized by positively charged residues (K48, R51, and R360) without the involvement of divalent cations (Figure 5B). 

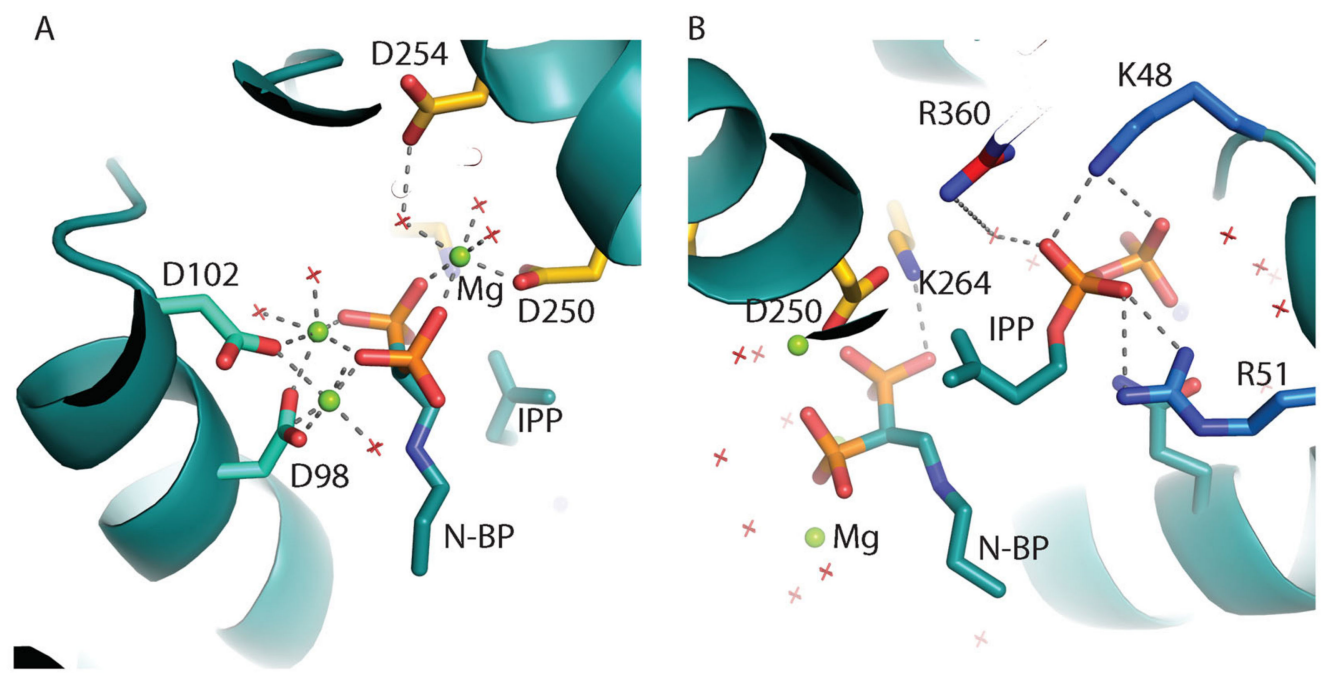

Figure 5. Active site of Trypanosoma cruzi farnesyl pyrophosphate synthase (FPPS) in complex with a N-BP ([2-(n-propylamino)ethane-1,1-diyl] bisphosphonic acid), $\mathrm{Mg}^{2+}$, and isopentenyl pyrophosphate (IPP) (PDB ID 4DXJ). (A) Coordination of $\mathrm{Mg}^{2+}$ is shown with grey dashed lines. Residues of the aspartate rich motifs are shown as sticks. Water molecules are shown as red crossmarks. (B) IPP is at hydrogen bonding distance of K48, R51, and R360.

\section{Conclusions and Perspectives}

NTDs represent a group of diseases that affect millions of individuals worldwide, resulting from the social and economic underdevelopment of developing countries [2]. In the context of these diseases, those caused by parasitic protozoa, such as Chagas disease and leishmaniasis, deserve special attention, mainly owing to the few therapeutic options, high toxicity associated with currently used drugs, difficulty of access, high cost, and low efficacy that interfere with treatment adherence. Thus, there is an urgent need to develop new drugs with novel modes of action that are more effective, cheaper, less toxic, and easy to administer.

In this sense, bisphosphonate compounds are presented in this work as potential new compounds with antiparasitic activity, as these compounds can be easily synthesized in different ways, facilitating the rational design of new molecules with high antiparasitic activity and low toxicity. On the other hand, some of these compounds are already being used in pharmacological therapy for bone diseases in humans, thus facilitating the practice of repositioning drugs.

Thanks to the ability of some of these compounds to inhibit the mevalonate pathway in different types of protozoa, mainly owing to their ability to inhibit the enzyme FPPS, an enzyme essential for isoprenoid biosynthesis in trypanosomatids, nitrogenous bisphosphonates appear to be promising for the study of structure-activity mechanisms of new compounds with antiparasitic activity. However, in addition to the pharmacological action, knowledge of the synthesis process of these compounds can facilitate the development of new ones that are less toxic and can be used more safely in the context of pharmacological treatment of Chagas disease and leishmaniasis. In conclusion, further pharmacological studies, chemical synthesis, and toxicology are necessary to move these compounds forward for use in antiparasitic drug therapy.

Author Contributions: M.S.S. and S.B.G. drew the proposal of the manuscript. J.C.B.S., J.A.d.M. and S.M. produced the first version of the manuscript. All authors participated actively in the writing and discussion of the manuscript. All authors read and approved the final version of the manuscript.

Funding: This work was funded by Global Health and Tropical Medicine (Grant number IHMT-UID/multi/ 04413/2013 and Grant number PTDC/CVT-CVT/28908/2017), Fundação para Ciência e Tecnologia (FCT), Portugal. 
Acknowledgments: J.C.B.S., J.A.M., J.W.F.O., C.J.M., and W.M.T.Q.M. thanks to the financial support (MSc, PhD, and Post-doctoral Fellowships) provided by Capes/Brazil. MSS thanks to CNPq/Brazil for the Research Grant (Bolsa de Produtividade). We are also grateful to Paulo Fanado for editing this manuscript.

Conflicts of Interest: The authors declare no conflict of interest.

\section{References}

1. World Health Organization. Neglected Tropical Diseases. Available online: https://www.who.int/neglected_ diseases/diseases/en/ (accessed on 27 May 2020).

2. Andrade, C.H.; Kümmerle, A.E.; Guido, R.V.C. Medicinal chemistry perspectives for the 21st century: Challenges and opprotunities. Quim. Nova 2018, 41, 476-483.

3. Weng, H.B.; Chen, H.X.; Wang, M.W. Innovation in neglected tropical disease drug discovery and development. Infect. Dis. Poverty 2018, 7, 1-9. [CrossRef] [PubMed]

4. Rugani, J.N.; Quaresma, P.F.; Gontijo, C.F.; Soares, R.P.; Monte-Neto, R.L. Intraspecies susceptibility of Leishmania (Viannia) braziliensis to antileishmanial drugs: Antimony resistance in human isolates from atypical lesions. Biomed. Pharmacother. 2018, 108, 1170-1180. [CrossRef]

5. Soeiro, M.D.N.C.; Souza, E.M.; Silva, C.F.; Batista, D.D.G.J.; Batista, M.M.; Pavão, B.P.; Britto, C. In vitro and in vivo studies of the antiparasitic activity of sterol $14 \alpha$-demethylase (CYP51) inhibitor VNI against drug-resistant strains of Trypanosoma cruzi. Antimicrob. Agents Chemother. 2013, 57, 4151-4163. [CrossRef] [PubMed]

6. Holanda, V.N.; Silva, W.V.; Nascimento, P.H.; Oliveira, R.N.; Lima, V.L.M.; Figueiredo, R.C.B.Q. Challengas and perspectives in the treatment of tegumentary leishmaniosis: Review. Rev. Interfaces Saúde Hum. Tecnol. 2018, 6, 140-157.

7. Aripirala, S.; Gonzalez-Pacanowska, D.; Oldfield, E.; Kaiser, M.; Amzel, L.M.; Gabelli, S.B. Structural and thermodynamic basis of the inhibition of Leishmania major farnesyl diphosphate synthase by nitrogen-containing bisphosphonates. Acta Crystallogr. D Biol. Crystallogr. 2014, 70, 802-810. [CrossRef]

8. Mukherjee, S.; Basu, S.; Zhang, K. Farnesyl pyrophosphate synthase is essential for the promastigote and amastigote stages in Leishmania major. Mol. Biochem. Parasitol. 2019, 230, 8-15. [CrossRef]

9. Ortiz-Gómez, A.; Jiménez, C.; Estévez, A.M.; Carrero-Lérida, J.; Ruiz-Pérez, L.M.; González-Pacanowska, D. Farnesyl diphosphate synthase is a cytosolic enzyme in Leishmania major promastigotes and its overexpression confers resistance to risedronate. Eukaryot. Cell 2006, 5, 1057-1064. [CrossRef]

10. Rodriguez, N.; Bailey, B.N.; Martin, M.B.; Oldfield, E.; Urbina, J.A.; Docampo, R. Radical cure of experimental cutaneous leishmaniasis by the bisphosphonate pamidronate. J. Infect. Dis. 2002, 186, 138-140. [CrossRef]

11. Aripirala, S.; Szajnman, S.H.; Jakoncic, J.; Rodriguez, J.B.; Docampo, R.; Gabelli, S.B.; Amzel, L.M. Design, synthesis, calorimetry and crystallographic analysis of 2-alkylaminoethyl-1,1-bisphosphonates as inhibitors of Trypanosoma cruzi farnesyl diphosphate synthase. J. Med. Chem. 2012, 55, 6445-6454. [CrossRef]

12. Galaka, T.; Falcone, B.N.; Li, C.; Szajnman, S.H.; Moreno, S.N.J.; Docampo, R.; Rodriguez, J.B. Synthesis and biological evaluation of 1-alkylaminomethyl-1,1-bisphosphonic acids against Trypanosoma cruzi and Toxoplasma gondii. Bioorg. Med. Chem. 2019, 27, 3663-3673. [CrossRef] [PubMed]

13. Garzoni, L.R.; Caldera, A.; Meirelles, M.D.N.L.; Castro, S.L.; Docampo, R.; Meints, G.A.; Oldfield, E.; Urbina, J.A. Selective in vitro effects of the farnesyl pyrophosphate synthase inhibitor risedronate on Trypanosoma cruzi. Int. J. Antimicrob. Agents 2004, 23, 273-285. [CrossRef] [PubMed]

14. Cheong, Y.-K.; Ren, G.G.; Huang, M.; Detsch, R.; Boccaccini, A.R. Biological evaluations of novel 2,3,3-trisphosphonate in osteoclastic and osteoblastic activities. Gen. Med. Open 2017, 2, 1-10. [CrossRef]

15. Chmielewska, E.; Kafarski, P. Physiologic activity of bisphosphonates-Recent advances. Open Pharm. Sci. J. 2016, 3, 56-78. [CrossRef]

16. Kuzuyama, T. Mevalonate and nonmevalonate pathways for the biosynthesis of isoprene units. Biosci. Biotechnol. Biochem. 2002, 66, 1619-1627. [CrossRef] [PubMed]

17. Boucher, Y.; Kamekura, M.; Doolittle, W.F. Origins and evolution of isoprenoid lipid biosynthesis in archaea. Mol. Microbiol. 2004, 52, 515-527. [CrossRef]

18. Vicent, D.; Maratos-Flier, E.; Kahn, C.R. The branch point enzyme of the mevalonate pathway for protein prenylation is overexpressed in the ob/ob mouse and induced by adipogenesis. Mol. Cell. Biol. 2000, 20, 2158-2166. [CrossRef] 
19. Cunillera, N.; Arró, M.; Delourme, D.; Karst, F.; Boronat, A.; Ferrer, A. Arabidopsis thaliana contains two differentially expressed farnesyl-diphosphate synthase genes. J. Biol. Chem. 1996, 271, 7774-7780. [CrossRef]

20. Daudonnet, S.; Karst, F.; Tourte, Y. Expression of the farnesyldiphosphate synthase gene of Saccharomyces cerevisiae in tobacco. Mol. Breed. 1997, 3, 137-145. [CrossRef]

21. Ohnuma, S.I.; Nakazawa, T.; Hemmi, H.; Hallberg, A.M.; Koyama, T.; Ogura, K.; Nishino, T. Conversion from farnesyl diphosphate synthase to geranylgeranyl diphosphate synthase by random chemical mutagenesis. J. Biol. Chem. 1996, 271, 10087-10095. [CrossRef]

22. Montalvetti, A.; Bailey, B.N.; Martin, M.B.; Severin, G.W.; Oldfield, E.; Docampo, R. Bisphosphonates are potent inhibitors of Trypanosoma cruzi farnesyl pyrophosphate synthase. J. Biol. Chem. 2001, 276, 33930-33937. [CrossRef] [PubMed]

23. Ghosh, S.; Chan, J.M.W.; Lea, C.R.; Meints, G.A.; Lewis, J.C.; Tovian, Z.S.; Flessner, R.M.; Loftus, T.C.; Bruchhaus, I.; Kendrick, H.; et al. Effects of bisphosphonates on the growth of Entamoeba histolytica and Plasmodium species in vitro and in vivo. J. Med. Chem. 2004, 47, 175-187. [CrossRef] [PubMed]

24. Ling, Y.; Li, Z.H.; Miranda, K.; Oldfield, E.; Moreno, S.N.J. The farnesyl-diphosphate/geranylgeranyldiphosphate synthase of Toxoplasma gondii is a bifunctional enzyme and a molecular target of bisphosphonates. J. Biol. Chem. 2007, 282, 30804-30816. [CrossRef] [PubMed]

25. Yardley, V.; Khan, A.A.; Martin, M.B.; Slifer, T.R.; Araujo, F.G.; Moreno, S.N.J.; Docampo, R.; Croft, S.L.; Oldfield, E. In vivo activities of farnesyl pyrophosphate synthase inhibitors against Leishmania donovani and Toxoplasma gondii. Antimicrob. Agents Chemother. 2002, 46, 929-931. [CrossRef]

26. Ling, Y.; Sahota, G.; Odeh, S.; Chan, J.M.W.; Araujo, F.G.; Moreno, S.N.J.; Oldfield, E. Bisphosphonate inhibitors of Toxoplasma gondii growth: In vitro, QSAR, and in vivo investigations. J. Med. Chem. 2005, 48, 3130-3140. [CrossRef]

27. Martin, M.B.; Grimley, J.S.; Lewis, J.C.; Heath, H.T.; Bailey, B.N.; Kendrick, H.; Yardley, V.; Caldera, A.; Lira, R.; Urbina, J.A.; et al. Bisphosphonates inhibit the growth of Trypanosoma brucei, Trypanosoma cruzi, Leishmania donovani, Toxoplasma gondii, and Plasmodium falciparum: A potential route to chemotherapy. J. Med. Chem. 2001, 44, 909-916. [CrossRef]

28. Moreno, S.N.J.; Li, Z.H. Targeting the isoprenoid pathway of Toxoplasma gondii. Expert Opin. Ther. Targets 2008, 12, 253-263. [CrossRef]

29. Rodan, G.A. Mechanisms of action of bisphosphonates. Annu. Rev. Pharmacol. Toxicol. 1998, 38, 375-388. [CrossRef]

30. Rosso, V.S.; Szajnman, S.H.; Malayil, L.; Galizzi, M.; Moreno, S.N.J.; Docampo, R.; Rodriguez, J.B. Synthesis and biological evaluation of new 2-alkylaminoethyl-1,1-bisphosphonic acids against Trypanosoma cruzi and Toxoplasma gondii targeting farnesyl diphosphate synthase. Bioorg. Med. Chem. 2011, 19, 2211-2217. [CrossRef]

31. Sarkar, S.; Strutz, S.E.; Frank, D.M.; Rivaldi, C.L.; Sissel, B.; Sánchez-Cordero, V. Chagas disease risk in Texas. PLoS Negl. Trop. Dis. 2010, 4, e836. [CrossRef]

32. Szajnman, S.H.; García Liñares, G.E.; Li, Z.H.; Jiang, C.; Galizzi, M.; Bontempi, E.J.; Ferella, M.; Moreno, S.N.J.; Docampo, R.; Rodriguez, J.B. Synthesis and biological evaluation of 2-alkylaminoethyl-1,1-bisphosphonic acids against Trypanosoma cruzi and Toxoplasma gondii targeting farnesyl diphosphate synthase. Bioorg. Med. Chem. 2008, 16, 3283-3290. [CrossRef] [PubMed]

33. Todolí, F.; Solano-Gallego, L.; Ojeda, A.; Quintana, J.; Lloret, A.; Roura, X.; Alberola, J.; Rodríguez-Cortés, A. Anti-Leishmania IgA in urine samples from dogs with clinical leishmaniasis. Vet. Parasitol. 2009, 159, 17-23. [CrossRef] [PubMed]

34. Leuret, F.; Lassaigne, J.L. Recherches Physiologiques et Chimiques pour Servir à L'histoire de la Digestion; Madame Huzard: Paris, France, 1825.

35. Allen, D.W. Phosphines and Related P-C-Bonded Compounds. In Organophosphorus Chemistry; Allen, D.W., Tebby, J.C., Loakes, D., Eds.; Royal Society of Chemistry: London, UK, 2014; Volume 43.

36. Fleisch, H.; Graham, R.; Russell, G.; Straumann, F. Effect of pyrophosphate on hydroxyapatite and its implications in calcium homeostasis. Nature 1966, 212, 901-903. [CrossRef] [PubMed]

37. Fleisch, H.; Bisaz, S. Isolation from urine of pyrophosphate, a calcification inhibitor. Am. J. Physiol. 1962, 203, 671-675. [CrossRef] [PubMed]

38. Rodan, G.A.; Fleisch, H.A. Bisphosphonates: Mechanisms of action. J. Clin. Investig. 2009, 97, $2692-2696$. [CrossRef] [PubMed] 
39. Blomen, L.J.M.J. History of the bisphosphonates: Discovery and history of the non- medical uses of bisphosphonates. In Bisphosphonates on Bones; Elsevier: Amsterdam, The Netherlands, 1995; pp. 111-124.

40. Galaka, T.; Casal, M.F.; Storey, M.; Li, C.; Chao, M.N.; Szajnman, S.H.; Docampo, R.; Moreno, S.N.J.; Rodriguez, J.B. Antiparasitic activity of sulfur- and fluorine-containing bisphosphonates against trypanosomatids and apicomplexan parasites. Molecules 2017, 22, 82. [CrossRef]

41. Ebetino, F.H.; Hogan, A.M.L.; Sun, S.; Tsoumpra, M.K.; Duan, X.; Triffitt, J.T.; Kwaasi, A.A.; Dunford, J.E.; Barnett, B.L.; Oppermann, U.; et al. The relationship between the chemistry and biological activity of the bisphosphonates. Bone 2011, 49, 20-33. [CrossRef]

42. Widler, L.; Jahnke, W.; Green, J.R. The chemistry of Bisphosphonates: From antiscaling agents to clinical therapeutics. Anti Cancer Agents Med. Chem. 2012, 12, 95-101. [CrossRef]

43. Rasmusson, L.; Abtahi, J. Bisphosphonate associated osteonecrosis of the jaw: An update on pathophysiology, risk factors, and treatment. Int. J. Dent. 2014, 2014, 471035. [CrossRef]

44. Forte, L.; Sarda, S.; Torricelli, P.; Combes, C.; Brouillet, F.; Marsan, O.; Salamanna, F.; Fini, M.; Boanini, E.; Bigi, A. Correction to "Multifunctionalization modulates hydroxyapatite surface interaction with bisphosphonate: Antiosteoporotic and antioxidative stress materials". ACS Biomater. Sci. Eng. 2019, 5, 3429-3439. [CrossRef]

45. Whitaker, M.; Guo, J.; Kehoe, T.; Benson, G. Bisphosphonates for osteoporosis-Where do we go from here? N. Eng. J. Med. 2012, 366, 2048-2051. [CrossRef] [PubMed]

46. Ermer, M.A.; Kottmann, S.C.; Otten, J.E.; Wittmer, A.; Poxleitner, P.; Pelz, K. In vitro investigation of the antimicrobial effect of three bisphosphonates against different bacterial strains. J. Oral Maxillofac. Surg. 2018, 76, 553-560. [CrossRef] [PubMed]

47. Green, J.; Lipton, A. Anticancer properties of zoledronic acid. Cancer Investig. 2010, 28, 944-957. [CrossRef] [PubMed]

48. Sanders, J.M.; Ghosh, S.; Chan, J.M.W.; Meints, G.; Wang, H.; Raker, A.M.; Song, Y.; Colantino, A.; Burzynska, A.; Kafarski, P.; et al. Quantitative structure-activity relationships for $\gamma \delta \mathrm{T}$ cell activation by bisphosphonates. J. Med. Chem. 2004, 47, 375-384. [CrossRef]

49. Martin, M.B.; Sanders, J.M.; Kendrick, H.; de Luca-Fradley, K.; Lewis, J.C.; Grimley, J.S.; Van Brussel, E.M.; Olsen, J.R.; Meints, G.A.; Burzynska, A.; et al. Activity of Bisphosphonates against Trypanosoma brucei rhodesiense. J. Med. Chem. 2002, 45, 2904-2914. [CrossRef]

50. Yang, G.; Zhu, W.; Kim, K.; Byun, S.Y.; Choi, G.; Wang, K.; Cha, J.S.; Cho, H.S.; Oldfield, E.; No, J.H. In vitro and in vivo investigation of the inhibition of Trypanossoma brucei cell growth by lipophilic bisphosphonates. Antimicrob. Agents Chemother. 2015, 59, 7530-7539. [CrossRef]

51. Lolli, M.L.; Lazzarato, L.; Di Stilo, A.; Fruttero, R.; Gasco, A. Michael addition of Grignard reagents to tetraethyl ethenylidenebisphosphonate. J. Organomet. Chem. 2002, 650, 77-83. [CrossRef]

52. Degenhardt, C.R.; Burdsall, D.C. Synthesis of ethenylidenebis(phosphonic acid) and its tetraalkyl esters. J. Org. Chem. 1986, 51, 3488-3490. [CrossRef]

53. Kieczykowski, G.R.; Jobson, R.B.; Melillo, D.G.; Reinhold, D.F.; Grenda, V.J.; Shinkai, I. Preparation or (4-Amino-l-hydroxybutylidene)bisphosphonic acid sodium Salt, MK-217 (Alendronate sodium). An improved procedure for the preparation of 1-Hydroxy-1,1-bisphosphonic acids. J. Org. Chem. 1995, 60, 8310-8312. [CrossRef]

54. Nguyen, L.M.; Niesor, E.; Bentzen, C.L. Gem-diphosphonate and gem -phosphonate-phosphate compounds with specific high density lipoprotein inducing activity. Am. Chem. Soc. 1987, 30, 1426-1433. [CrossRef]

55. Lai, C.; Xi, C.; Feng, Y. A facile approach for the synthesis of $\alpha$-halogenated alkylidenediphosphonates by reaction of alkyllithium with chlorophosphate and halogen reagent. Phosphorus Sulfur Silicon Relat. Elem. 2004, 179, 449-455. [CrossRef]

56. Teulade, M.P.; Savignac, P.; Aboujaoude, E.E.; Liétge, S.; Collignon, N. Alkylidènediphosphonates et vinylphosphonates: Une démarche synthétiques sélective par voie carbanionique. J. Organomet. Chem. 1986, 304, 283-300. [CrossRef]

57. Hutchinson, D.W.; Thornton, D.M. Michael addition reactions of ethenylidenebisphosphonates. J. Organomet. Chem. 1988, 346, 341-348. [CrossRef]

58. Lehnert, W. Knoevenagel kondensationen mit TiCl4/base-IV. Umsetzungen von aldehyden und ketonen mit phosphonoessigester und methylendiphosphonsäureestern. Tetrahedron 1974, 30, 301-305. [CrossRef] 
59. Inoue, S.; Okauchi, T.; Minami, T. New synthesis of gem-bis(phosphono)ethylenes and their applications. Synthesis 2003, 13, 1971-1976. [CrossRef]

60. Yokomatsu, T.; Yoshida, Y.; Nakabayashi, N.; Shibuya, S. Simple and efficient method for preparation of conformationally constrained aminomethylene gem-diphosphonate derivatives via beckmann rearrangement. J. Org. Chem. 1994, 59, 7562-7564. [CrossRef]

61. Wu, M.; Chen, R.; Huang, Y. Convenient synthesis of analogs of aminomethylene gem-diphosphonic acid from amines without catalyst. Synth. Commun. 2004, 34, 1393-1398. [CrossRef]

62. Gouault-Bironneau, S.; Deprèle, S.; Sutor, A.; Montchamp, J.L. Radical reaction of sodium hypophosphite with terminal alkynes: Synthesis of 1,1-bis-H-phosphinates. Org. Lett. 2005, 7, 5909-5912. [CrossRef]

63. Romanenko, V.; Kukhar, V. Progress in the development of pyrophosphate bioisosteres: Synthesis and biomedical potential of 1-Fluoro- and 1,1-Difluoromethylene-1,1-bisphosphonates. Curr. Org. Chem. 2016, 18, 1491-1512. [CrossRef]

64. Puljula, E.; Turhanen, P.; Vepsäläinen, J.; Monteil, M.; Lecouvey, M.; Weisell, J. Structural requirements for bisphosphonate binding on hydroxyapatite: NMR study of bisphosphonate partial esters. ACS Med. Chem. Lett. 2015, 6, 397-401. [CrossRef]

65. Qian, D.Q.; Shi, X.D.; Zeng, X.Z.; Cao, R.Z.; Liu, L.Z. Aminoalkylation of organophosphorus compounds with P-H bond by using Vilsmeier reagents. Tetrahedron Lett. 1997, 38, 6245-6246.

66. Docampo, R.; Moreno, S.N. Bisphosphonates as chemotherapeutic agents against trypanosomatid and apicomplexan parasites. Curr. Drug Targets Infect. Disord. 2001, 1, 51-61. [CrossRef] [PubMed]

67. Suzuki, K.; Nagaoka, M.; Igarashi, K.; Hisashi, S. MPMBP, a novel bisphosphonate with an antioxidant side chain, stimulates bone formation through inhibition of NF-кB nuclear translocation. Folia Pharmacol. Jpn. 2019, 153, 4-10. [CrossRef] [PubMed]

68. Bigi, A.; Boanini, E. Calcium phosphates as delivery systems for bisphosphonates. J. Funct. Biomater. 2018, 9, 6. [CrossRef]

69. Cromartie, T.H.; Fisher, K.J.; Grossman, J.N. The discovery of a novel site of action for herbicidal bisphosphonates. Pestic. Biochem. Physiol. 1999, 63, 114-126. [CrossRef]

70. Giger, E.V.; Castagner, B.; Leroux, J.C. Biomedical applications of bisphosphonates. J. Control. Release 2013, 167, 175-188. [CrossRef]

71. Russell, R.G.G. Bisphosphonates: Mode of Action and Pharmacology. Pediatrics 2007, 119, 150-162. [CrossRef]

72. Russell, R.G. Bisphosphonates: The first 40 years. Bone 2011, 49, 2-19. [CrossRef]

73. Rodan, G.A.; Reszka, A.A. Bisphosphonate mechanism of action. Curr. Rheumatol. Rep. 2003, 2, 571-577.

74. Frith, J.C.; Mönkkönen, J.; Blackburn, G.M.; Russell, R.G.G.; Rogers, M.J. Clodronate and liposome-encapsulated clodronate are metabolized to a toxic ATP analog, adenosine 5'-(beta, gamma-dichloromethylene) triphosphate, by mammalian cells in vitro. J. Bone Miner. Res. 1997, 12, 1358-1367. [CrossRef]

75. Ebetino, F.H.; Francis, M.D.; Rogers, M.J.; Russell, R.G.G. Mechanisms of action of etidronate and other bisphosphonates. Rev. Contemp. Pharmaco. 1998, 9, 233-243.

76. Coleman, R.E. Risks and benefits of bisphosphonates. Br. J. Cancer 2008, 98, 1736-1740. [CrossRef] [PubMed]

77. Coxon, F.P.; Thompson, K.; Rogers, M.J. Recent advances in understanding the mechanism of action of bisphosphonates. Curr. Opin. Pharmacol. 2006, 6, 307-312. [CrossRef] [PubMed]

78. Martin, M.B.; Arnold, W.; Heath, H.T.; Urbina, J.A.; Oldfield, E. Nitrogen-containing bisphosphonates as carbocation transition state analogs for isoprenoid biosynthesis. Biochem. Biophys. Res. Commun. 1999, 263, 754-758. [CrossRef]

79. Reszka, A.A.; Rodan, G.A. Nitrogen-containing bisphosphonate mechanism of action. Curr. Rheumatol. Rep. 2003, 5, 65-74. [CrossRef]

80. Reszka, A.A.; Rodan, G.A. Mechanism of action of bisphosphonates. Curr. Osteoporos. Rep. 2003, 1, 45-52. [CrossRef] [PubMed]

81. Cremers, S.; Papapoulos, S. Pharmacology of bisphosphonates. Bone 2011, 49, 42-49. [CrossRef]

82. Zhang, L.; Ko, T.P.; Malwal, S.R.; Liu, W.; Zhou, S.; Yu, X.; Oldfield, E.; Guo, R.T.; Chen, C.C. Complex structures of MoeN5 with substrate analogues suggest sequential catalytic mechanism. Biochem. Biophys. Res. Commun. 2019, 511, 800-805. [CrossRef]

83. Huang, C.H.; Gabelli, S.B.; Oldfield, E.; Mario Amzel, L. Binding of nitrogen-containing bisphosphonstes (N-BPs) to the Trypanosoma cruzi fernesyl diphosphate synthase homodimer. Proteins Struct. Funct. Bioinform. 2010, 78, 888-899. [CrossRef] 
84. Pool, F.; Currie, R.; Sweby, P.K.; Salazar, J.D.; Tindall, M.J. A mathematical model of the mevalonate cholesterol biosynthesis pathway. J. Theor. Biol. 2018, 443, 157-176. [CrossRef]

85. Bishop, N.J.; Russell, G. Bisphosphonates. In Osteogenesis Imperfecta; Shapiro, J.R., Byers, P.H., Glorieux, F.H., Sponseller, P.D., Eds.; Academic Press: San Diego, CA, USA, 2014; pp. 495-500. ISBN 978-0-12-397165-4.

86. Kumar, V.; Shahi, A.K. Nitrogen containing bisphosphonates associated osteonecrosis of the jaws: A review for past 10 year literature. Dent. Res. J. 2014, 11, 147.

87. Sigman, L.; Sánchez, V.M.; Turjanski, A.G. Characterization of the farnesyl pyrophosphate synthase of Trypanosoma cruzi by homology modeling and molecular dynamics. J. Mol. Graph. Model. 2006, 25, 345-352. [CrossRef] [PubMed]

88. Sumbria, D.; Singla, L.D. Pharmacokinetics and pharmacology to drugs used for control of emerging cryptosporidiosis and toxoplasmosis in livestock and humans. J. Entomol. Zool. Stud. 2019, 7, 1306-1313.

89. Chagas, C. Nova tripanozomiaze humana: Estudos sobre a morfologia e o ciclo evolutive do Schizotrypanum cruzi n. gen. n. sp., agente etiológico de nova entidade mórbida do homem. Mem. Inst. Oswaldo Cruz 1909, 1, 159-218. [CrossRef]

90. Requena-Méndez, A.; Aldasoro, E.; de Lazzari, E.; Sicuri, E.; Brown, M.; Moore, D.A.J.; Gascon, J.; Muñoz, J. Prevalence of Chagas Disease in Latin-American Migrants Living in Europe: A systematic review and meta-analysis. PLoS Negl. Trop. Dis. 2015, 9, e0003540. [CrossRef] [PubMed]

91. Molina, I.; Salvador, F.; Sánchez-Montalvá, A.; Treviño, B.; Serre, N.; Avilés, A.S.; Almirante, B. Toxic profile of benznidazole in patients with chronic chagas disease: Risk factors and comparison of the product from two different manufacturers. Antimicrob. Agents Chemother. 2015, 59, 6125-6131. [CrossRef]

92. Pérez-Molina, J.A.; Molina, I. Chagas Disease. Seminar. Lancet 2018, 391, 82-94. [CrossRef]

93. Rassi, A.; Marin-Neto, J.A.; Rassi, A. Chronic chagas cardiomyopathy: A review of the main pathogenic mechanisms and the efficacy of aetiological treatment following the benznidazole evaluation for interrupting trypanosomiasis (BENEFIT) trial. Mem. Inst. Oswaldo Cruz 2017, 112, 224-235. [CrossRef]

94. World Health Organization. Chagas Disease (Also Known as American Trypanosomiasis). Available online: https://www.who.int/news-room/fact-sheets/detail/chagas-disease-(american-trypanosomiasis) (accessed on 27 May 2020).

95. World Health Organization. Research Priorities for Chagas Disease, Human African Trypanosomiasis and Leishmaniasis. In World Health Organization Technical Report Series; WHO: Geneva, Switzerland, 2012; pp. 1-100.

96. Coura, J.R.; Borges-Pereira, J. Chagas disease: 100 years after its discovery. A systemic review. Acta Trop. 2010, 115, 5-13. [CrossRef]

97. Hotez, P.J.; Woc-Colburn, L.; Bottazzi, M.E. Neglected tropical diseases in Central America and Panama: Review of their prevalence, populations at risk and impact on regional development. Int. J. Parasitol. 2014, 44, 597-603. [CrossRef]

98. Pan American Health Organization. Chagas disease in the Americas: A Review of the Current Public Health Situation and a Vision for the Future. Available online: https://www.paho.org/hq/index.php?option=com content\&view=category\&id=3591\&Itemid=40370\&lang=en (accessed on 27 May 2020).

99. Edwards, M.S.; Stimpert, K.K.; Bialek, S.R.; Montgomery, S.P. Evaluation and management of congenital chagas disease in the United States. J. Pediatric Infect. Dis. Soc. 2019, 8, 461-469. [CrossRef] [PubMed]

100. Hotez, P.J.; Dumonteil, E.; Betancourt Cravioto, M.; Bottazzi, M.E.; Tapia-Conyer, R.; Meymandi, S.; Karunakara, U.; Ribeiro, I.; Cohen, R.M.; Pecoul, B. An unfolding tragedy of chagas disease in North America. PLoS Negl. Trop. Dis. 2013, 7, 2300-2304. [CrossRef] [PubMed]

101. Bern, C.; Montgomery, S.P. An estimate of the burden of chagas disease in the United States. Clin. Infect. Dis. 2009, 49, 52-54. [CrossRef] [PubMed]

102. Vincent, A.; Newsom-Davis, J.; Wray, D.; Shillito, P.; Harrison, J.; Betty, M.; Murray, N. Clinical and experimental-Observations in patients with congenital myasthenic syndromes. Ann. N. Y. Acad. Sci. 1993, 681, 451-460. [CrossRef]

103. Quaresma, P.F.; De Brito, C.F.A.; Rugani, J.M.N.; Freire, J.D.M.; Baptista, R.D.P.; Moreno, E.C.; Gontijo, R.C.; Rego, F.D.; Diniz, J.E.; Melo, M.N.; et al. Distinct genetic profiles of Leishmania (Viannia) braziliensis associate with clinical variations in cutaneous-leishmaniasis patients from an endemic area in Brazil. Proc. Int. Astron. Union 2018, 145, 1161-1169. [CrossRef] 
104. Chatelain, E. Chagas disease research and development: Is there light at the end of the tunnel? Comput. Struct. Biotechnol. J. 2017, 15, 98-103. [CrossRef]

105. Pérez-Ayala, A.; Pérez-Molina, J.A.; Norman, F.; Monge-Maillo, B.; Faro, M.V.; López-Vélez, R. Gastro-intestinal chagas disease in migrants to spain: Prevalence and methods for early diagnosis. Ann. Trop. Med. Parasitol. 2011, 105, 25-29. [CrossRef]

106. Pinazo, M.J.; Espinosa, G.; Gállego, M.; López-Chejade, P.L.; Urbina, J.A.; Gascón, J. Case report: Successful treatment with posaconazole of a patient with chronic Chagas disease and systemic lupus erythematosus. Am. J. Trop. Med. Hyg. 2010, 82, 583-587. [CrossRef]

107. Urbina, J.A. Specific chemotherapy of Chagas disease: Relevance, current limitations and new approaches. Acta Trop. 2010, 115, 55-68. [CrossRef]

108. Bern, C.; Martin, D.L.; Gilman, R.H. Acute and Congenital Chagas Disease. Adv. Parasitol. 2011, 75, $19-47$.

109. Ferella, M.; Li, Z.H.; Andersson, B.; Docampo, R. Farnesyl diphosphate synthase localizes to the cytoplasm of Trypanosoma cruzi and T. brucei. Exp. Parasitol. 2008, 119, 308-312. [CrossRef] [PubMed]

110. Cuevas, I.C.; Rohloff, P.; Sánchez, D.O.; Docampo, R. Characterization of farnesylated protein tyrosine phosphatase TcPRL-1 from Trypanosoma cruzi. Eukaryot. Cell 2005, 4, 1550-1561. [CrossRef] [PubMed]

111. Nepomuceno-Silva, J.L.; Yokoyama, K.; De Mello, L.D.B.; Mendonça, S.M.; Paixaøo, J.C.; Baron, R.; Faye, J.C.; Buckner, F.S.; Van Voorhis, W.C.; Gelb, M.H.; et al. TcRho1, a farnesylated Rho family homologue from Trypanosoma cruzi. Cloning, trans-splicing, and prenylation studies. J. Biol. Chem. 2001, 276, 29711-29718. [CrossRef] [PubMed]

112. Docampo, R.; de Boiso, J.F.; Stoppani, A.O.M. Bba 47498 tricarboxylic acid cycle operation at the kinetoplastmitochondrion complex of Trypanosoma cruzi. Biochim. Biophys. Acta Bioenerg. 1978, 502, 466-476. [CrossRef]

113. Parod, A.J.; Quesada-Allue, L.A. Protein glycosylation in Trypanosoma cruzi. I. Characterization of dolichol-bound monosaccharides and oligosaccharides synthesized in vivo. J. Biol. Chem. 1982, 257, 7637-7640.

114. Ferella, M.; Montalvetti, A.; Rohloff, P.; Miranda, K.; Fang, J.; Reina, S.; Kawamukai, M.; Búa, J.; Nilsson, D.; Pravia, C.; et al. A solanesyl-diphosphate synthase localizes in glycosomes of Trypanosoma cruzi. J. Biol. Chem. 2006, 281, 39339-39348. [CrossRef]

115. Docampo, R.; Moreno, S.N.; Turrens, J.F.; Katzin, A.M.; Gonzalez-Cappa, S.M.; Stoppani, A.O. Biochemical and ultrastructural alterations produced by miconazole and econazole in Trypanosoma cruzi. Mol. Biochem. Parasitol. 1981, 3, 169-180. [CrossRef]

116. Bouzahzah, B.; Jelicks, L.A.; Morris, S.A.; Weiss, L.M.; Tanowitz, H.B. Risedronate in the treatment of Murine Chagas' disease. Parasitol. Res. 2005, 96, 184-187. [CrossRef]

117. Dunford, J.E.; Thompson, K.; Coxon, F.P.; Luckman, S.P.; Hahn, F.M.; Poulter, C.D.; Ebetino, F.H.; Rogers, M.J. Structure-Activity relationships for inhibition of farnesyl diphosphate synthase in vitro and inhibition of bone resorption in vivo by nitrogen-containing bisphosphonates. J. Pharmacol. Exp. Ther. 2001, 296, $235-242$.

118. Urbina, J.A.; Moreno, B.; Vierkotter, S.; Oldfield, E.; Payares, G.; Sanoja, C.; Bailey, B.N.; Yan, W.; Scott, D.A.; Moreno, S.N.J.; et al. Trypanosoma cruzi contains major pyrophosphate stores, and its growth in vitro and in vivo is blocked by pyrophosphate analogs. J. Biol. Chem. 1999, 274, 33609-33615. [CrossRef]

119. Brown, D.L.; Robbins, R. Developments in the therapeutic applications of Bisphosphonates. J. Clin. Pharmacol. 1999, 39, 651-660. [CrossRef] [PubMed]

120. Szajnman, S.H.; Bailey, B.N.; Docampo, R.; Rodriguez, J.B. Bisphosphonates derived from fatty acids are potent growth inhibitors of Trypanosoma cruzi. Bioorg. Med. Chem. Lett. 2001, 11, 789-792. [CrossRef]

121. Demoro, B.; Rostán, S.; Moncada, M.; Li, Z.H.; Docampo, R.; Olea Azar, C.; Maya, J.D.; Torres, J.; Gambino, D.; Otero, L. Ibandronate metal complexes: Solution behavior and antiparasitic activity. J. Biol. Inorg. Chem. 2018, 23, 303-312. [CrossRef] [PubMed]

122. Gabelli, S.B.; McLellan, J.S.; Montalvetti, A.; Oldfield, E.; Docampo, R.; Amzel, L.M. Structure and mechanism of the farnesyl diphosphate synthase from Trypanosoma cruzi: Implications for drug design. Proteins Struct. Funct. Genet. 2006, 62, 80-88. [CrossRef]

123. Sanders, J.M.; Song, Y.; Chan, J.M.W.; Zhang, Y.; Jennings, S.; Kosztowski, T.; Odeh, S.; Flessner, R.; Schwerdtfeger, C.; Kotsikorou, E.; et al. Pyridinium-1-yl bisphosphonates are potent inhibitors of farnesyl diphosphate synthase and bone resorption. J. Med. Chem. 2005, 48, 2957-2963. [CrossRef]

124. Demoro, B.; Caruso, F.; Rossi, M.; Benítez, D.; Gonzalez, M.; Cerecetto, H.; Otero, L. Risedronate metal complexes potentially active against Chagas disease. J. Inorg. Biochem. 2010, 104, 1252-1258. [CrossRef] 
125. Freitas-Junior, L.H.; Chatelain, E.; Kim, H.A.; Siqueira-Neto, J.L. Visceral leishmaniasis treatment: What do we have, what do we need and how to deliver it? Int. J. Parasitol. Drugs Drug Resist. 2012, 2, 11-19. [CrossRef]

126. Lago, J.; Silva, J.A.; Borja, L.; Fraga, D.B.M.; Schriefer, A.; Arruda, S.; Lago, E.; Carvalho, E.M.; Bacellar, O. Clinical and histopathologic features of canine tegumentary leishmaniasis and the molecular characterization of Leishmania braziliensis in dogs. PLoS Negl. Trop. Dis. 2019, 13. [CrossRef]

127. Lainson, R.; Shaw, J.J. Leishmaniasis of the New World: Taxonomic Problems. Br. Med. Bull. 1972, $28,44-48$. [CrossRef]

128. World Health Organization. Leishmaniasis. Available online: https://www.who.int/leishmaniasis/en/ (accessed on 30 May 2020).

129. Akhoundi, M.; Downing, T.; Votýpka, J.; Kuhls, K.; Lukeš, J.; Cannet, A.; Ravel, C.; Marty, P.; Delaunay, P.; Kasbari, M.; et al. Leishmania infections: Molecular targets and diagnosis. Mol. Asp. Med. 2017, 57, 1-29. [CrossRef]

130. Porcino, G.N.; Carvalho, K.S.S.; Braz, D.C.; Costa Silva, V.; Costa, C.H.N.; Santos, I.K.F.M. Evaluation of methods for detection of asymptomatic individuals infected with Leishmania infantum in the state of Piauí, Brazil. PLoS Negl. Trop. Dis. 2019, 13, e0007493. [CrossRef] [PubMed]

131. Ponte-Sucre, A.; Gamarro, F.; Dujardin, J.C.; Barrett, M.P.; López-Vélez, R.; García-Hernández, R.; Pountain, A.W.; Mwenechanya, R.; Papadopoulou, B. Drug resistance and treatment failure in leishmaniasis: A 21st century challenge. PLoS Negl. Trop. Dis. 2017, 11, 1-24. [CrossRef] [PubMed]

132. Trinconi, C.T.; Miguel, D.C.; Silber, A.M.; Brown, C.; Mina, J.G.M.; Denny, P.W.; Heise, N.; Uliana, S.R.B. Tamoxifen inhibits the biosynthesis of inositolphosphorylceramide in Leishmania. Int. J. Parasitol. Drugs Drug Resist. 2018, 8, 475-487. [CrossRef] [PubMed]

133. Weina, P.J.; Neafie, R.C.; Wortmann, G.; Polhemus, M.; Aronson, N.E. Old world leishmaniasis: An emerging infection among deployed US military and civilian workers. Clin. Infect. Dis. 2004, 39, 1674-1680. [CrossRef]

134. Kreston, R. Discover Magazine Science for the Curious, 2011. Available online: https://www.discovermagazine. com/health/behind-enemy-lines-cutaneous-leishmaniasis-in-returning-us-troops-from-the-middle-east (accessed on 30 May 2020).

135. Defense Base Act Compensation Blog-The Modern Day DBA Casualty. Available online: https: //defensebaseactcomp.wordpress.com/2010/05/27/leishmaniasis-a-family-affair/ (accessed on 30 May 2020).

136. Clarke, C.F.; Bradley, K.K.; Wright, J.H.; Glowicz, J. Case report: Emergence of autochthonous cutaneous leishmaniasis in northeastern Texas and southeastern Oklahoma. Am. J. Trop. Med. Hyg. 2013, 88, 157-161. [CrossRef]

137. Beaumier, C.M.; Gomez-Rubio, A.M.; Hotez, P.J.; Weina, P.J. United States Military Tropical Medicine: Extraordinary Legacy, Uncertain Future. PLoS Negl. Trop. Dis. 2013, 7, 2448-2454. [CrossRef]

138. Menezes, J.P.B.; Guedes, C.E.S.; Petersen, A.L.d.O.A.; Fraga, D.B.M.; Veras, P.S.T. Advances in development of new treatment for leishmaniasis. BioMed Res. Int. 2015, 2015, 15-18. [CrossRef]

139. Wijnant, G.J.; Van Bocxlaer, K.; Yardley, V.; Harris, A.; Alavijeh, M.; Silva-Pedrosa, R.; Antunes, S.; Mauricio, I.; Murdan, S.; Croft, S.L. Comparative efficacy, toxicity and biodistribution of the liposomal amphotericin B formulations Fungisome ${ }^{\circledR}$ and AmBisome ${ }^{\circledR}$ in murine cutaneous leishmaniasis. Int. J. Parasitol. Drugs Drug Resist. 2018, 8, 223-228. [CrossRef]

140. Sundar, S.; Singh, A. Recent developments and future prospects in the treatment of visceral leishmaniasis. Ther. Adv. Infect. Dis. 2016, 3, 98-109. [CrossRef]

141. Dos Santos Nogueira, F.; Avino, V.C.; Galvis-Ovallos, F.; Pereira-Chioccola, V.L.; Moreira, M.A.B.; Romariz, A.P.P.L.; Molla, L.M.; Menz, I. Use of miltefosine to treat canine visceral leishmaniasis caused by Leishmania infantum in Brazil. Parasites Vectors 2019, 12, 1-11. [CrossRef]

142. Centers for Disease Control and Prevention. Resources for Health Professionals. Available online: https: //www.cdc.gov/parasites/leishmaniasis/health_professionals/index.html (accessed on 30 May 2020).

143. Copeland, N.K.; Aronson, N.E. Leishmaniasis: Treatment updates and clinical practice guidelines review. Curr. Opin. Infect. Dis. 2015, 28, 426-437. [CrossRef] [PubMed]

144. Alcântara, L.M.; Ferreira, T.C.S.; Gadelha, F.R.; Miguel, D.C. Challenges in drug discovery targeting TriTryp diseases with an emphasis on leishmaniasis. Int. J. Parasitol. Drugs Drug Resist. 2018, 8, 430-439. [CrossRef] [PubMed]

145. Gadelha, A.P.R.; Brigagao, C.M.; da Silva, M.B.; Rodrigues, A.B.M.; Guimarães, A.C.R.; Paiva, F.; de Souza, W.; Henriques, C. Insights about the structure of farnesyl diphosphate synthase (FPPS) and the activity of 
bisphosphonates on the proliferation and ultrastructure of Leishmania and Giardia. Parasites Vectors 2020, 13, 168. [CrossRef] [PubMed]

146. Kavanagh, K.L.; Guo, K.; Dunford, J.E.; Wu, X.; Knapp, S.; Ebetino, F.H.; Rogers, M.J.; Russell, R.G.G.; Oppermann, U. The molecular mechanism of nitrogen-containing bisphosphonates as antiosteoporosis drugs. Proc. Natl. Acad. Sci. USA 2006, 103, 7829-7834. [CrossRef]

147. Huang, C.H.; Gabelli, S.B.; Docampo, R.; Oldfield, E.; Amzel, L.M. Structural basis for bisphosphonate inhibition of T-cruzi farnesyl diphosphate synthase. Biophys. J. 2007, 317-318.

148. Tarshis, L.C.; Yan, M.; Poulter, C.D.; Sacchettini, J.C. Crystal structure of recombinant farnesyl diphosphate synthase at 2.6-.ANG. Resolution. Biochemistry 1994, 33, 10871-10877. [CrossRef]

Sample Availability: Samples of the compounds are not available from the authors.

(C) 2020 by the authors. Licensee MDPI, Basel, Switzerland. This article is an open access article distributed under the terms and conditions of the Creative Commons Attribution (CC BY) license (http://creativecommons.org/licenses/by/4.0/). 